\title{
PROFILE OF MEDICATION USE AND HEALTH OF PATIENTS WITH RHEUMATOID ARTHRITIS ATTENDED IN A RHEUMATOID ARTHRITIS AMBULATORY CLINIC OF A UNIVERSITY HOSPITAL
}

THUANE SALES GONÇALVES (Universidade Federal de Minas Gerais, Belo Horizonte, MG, Brasil), ISABELA VIANA OLIVEIRA (Universidade Federal de Minas Gerais, Belo Horizonte, MG, Brasil), HÁGABO MATHYELL SILVA (Universidade Federal de Minas Gerais, Belo Horizonte, MG, Brasil), CARINA MORAIS NEVES (Universidade Federal de Minas Gerais, Belo Horizonte, MG, Brasil), MARIANA MARTINS GONZAGA NASCIMENTO (Universidade Federal de Minas Gerais, Belo Horizonte, MG, Brasil), DJENANE RAMALHO DE OLIVEIRA (Universidade Federal de Minas Gerais, Belo Horizonte, MG, Brasil)

\section{BACKGROUND}

Rheumatoid arthritis (RA) is a chronic and systemic inflammatory disease of an autoimmune nature that affects the synovial membrane of the joints and, when not properly treated, causes loss of functional capacity and increased mortality. The treatment of RA involves different types of drugs with preestablished criteria of use that are adopted as the patient evolves. The safety profile of these drugs and the heterogeneity of their action require regular monitoring of their effectiveness and safety parameters. The aim of the present study was to describe the profile of drug use and health of patients with RA attended in a rheumatology clinic.

\section{MATERIALS AND METHODS}

This is a cross-sectional study based on the medical records of 201 patients.

\section{RESULTS}

An average age of 60 years were detected. In addition to RA, $97.5 \%$ of the patients had at least one other comorbidity, and systemic arterial hypertension $(52.7 \%)$ was the most prevalent. The patients used a total of 1,826 medications, with an average of $9.1 \pm 3.3$ and $94.5 \%$ used 5 or more medications. The most commonly used agent for the treatment of RA was prednisone $(53.2 \%)$, followed by methotrexate $(50.7 \%)$, leflunomide $(42.3 \%)$, and biological agents $(41.8 \%)$. The majority of the patients $(89.6 \%)$ also used at least one adjuvant medication to control adverse effects and $31.3 \%$ also used at least one adjuvant medication to contro

\section{CONCLUSION}

It was evidenced a complex profile of drug use due to the characteristics of the disease and associated comorbidities, which requires an adequate global approach to patients' drug therapy. 